\title{
Keys to learning Physical Education during confinement Claves para aprender Educación Física durante el confinamiento
}

*Sagrario Del Valle Díaz, *Esther Cabanillas Cruz, **Eduardo Villamil Cabello, ***Ricardo de la Vega Marcos

Universidad de Casrilla-La Mancha (Spain), **Superior Center Don Bosco (Spain), ***Universidad Autónoma de Madrid

(Spain)

\begin{abstract}
The purpose of this study was to identify the relationship between learning physical education competence, teachers' competence and students' motivation in quarantine. A primary goal of physical education is to develop competence in physically literate individuals with the knowledge, skills, and confidence necessary for a physically active lifestyle. Guided by the teachers' competence and expectancy-value and interest motivation theories. Method: 686 high school students (297 male and 390 women) from 17 Spanish regions of different social classes and level of instruction, provided data on expectancy beliefs and perceived knowledge of learning competence of physical education, intrinsic motivation, and teachers' competence. Data were analyzed using descriptive statistics and a simultaneous multiple regression model. To determine the best predictor of each subscale of the learning competence of physical education four parallel mediation models were examined. The mediation models were conducted to test «simultaneous mediation by multiple variables» Results: It was found that teacher competence was a significant predictor of knowledge transference $(b=.42$, s.e. $=.02, p<.001)$, mediated by psychological needs competence, autonomy, and relatedness. The standardized regression coefficient for this path is .42 . The total indirect effect was significant $(.17, \mathrm{CI}[.13, .21])$. Conclusion: This study demonstrates that teacher competence was a significant predictor of learning physical education competence mediated by psychological needs competence. Students' beliefs about success in physical education have a limited influence on the teachers' competence and knowing how to attend to the basic psychological needs of the students, in confinement.
\end{abstract}

Keywords: Physical Education, Sport, high school students, COVID-19, teachers' competence, psychological needs competence, confinement.

Resumen. El propósito de este estudio es identificar la relación existente entre el aprendizaje en educación física, la competencia de los docentes y la motivación de los estudiantes durante la cuarentena. Han participado 686 estudiantes de secundaria (297 hombres y 390 mujeres), con diferente clase social y nivel de instrucción, todos ellos proporcionaron datos sobre el conocimiento percibido del aprendizaje en educación física, la motivación intrínseca respecto a sus necesidades psicológicas básicas y la competencia de los profesores. Los datos se analizaron mediante estadística descriptiva y un modelo de regresión múltiple simultánea. Para determinar el mejor predictor de cada subescala del aprendizaje de educación física se examinaron cuatro modelos de mediación paralelos. Los modelos de mediación se realizaron para probar la «mediación simultánea por múltiples variables». Se encontró que la competencia docente fue un predictor significativo de la transferencia de conocimiento $(\mathrm{b}=.42, \mathrm{se}=.02, \mathrm{p}<.001)$, mediada por necesidades psicológicas competencia, autonomía y relación. El coeficiente de regresión estandarizado fue .42. El efecto indirecto total fue significativo (.17, IC [.13, .21]). Este estudio demuestra que la competencia docente fue un predictor significativo del aprendizaje de la educación física mediado por las necesidades psicológicas básicas de los estudiantes en el confinamiento.

Palabras clave: Educación Física, Deporte, Secundaria, COVID-19, competencia del profesorado, necesidades psicológicas básicas, confinamiento.

\section{Introduction}

2019 will be recall in history books as the year of coronavirus disease (COVID-19) pandemic. On March 18, 2020, the UN Educational, Scientific and Cultural Organization estimated that 107 countries had implemented national school closures related to

Fecha recepción: 24-06-21. Fecha de aceptación: 09-09-21

Sagrario del Valle Díaz

sagrariodel.valle@uclm.es
COVID-19, affecting 862 million children and young people, roughly half the global student population (Viner et al., 2020). One among all these countries is Spain who declared the state of alarm on March 14, 2020 (BOE, 2020).

The COVID-19 pandemic interrupted schooling in most countries of the world. Confinement measure change learning. Students in high school had seen their academic progress interrupted or at least modified in several ways. Different studies explore the effects that this measure have on the educational system (UNESCO, 
2020; Chen; Mao, Nassis, Harmer, et al., 2020; Huang, Liu, Tlili,Yang, et al., 2020; World Health Organization, 2020). Their findings illustrate the need to prioritize varying levels of psychological needs and health of students. Also, students need to find new ways to use learning tools effectively and communicate. Offline learning materials and programmers for young students in physical education deserve consideration. Physical Education learning, as a subject where its contents are mainly practical, may have seen their student's progress, in terms of skill execution and overall sport performance, compromised.

This study analyzes the influence of home confinement during the COVID-19 pandemic outbreak on high school students' focused on effectively is learning on physical education program, how affecting motivational status in his psychological needs, and the influence of the teachers' competence, to be active and healthy.

Adolescence search for self-identity, face psychological, physical, intellectual, and emotional concerns and challenges, and explore new roles. Individuation and separation are processing that adolescent must go through. Achieving autonomy and independence, setting personal goals, and making plans, and acquiring values and ethics are developmental tasks that all adolescents must realize. Adolescence has captured so much attention publicly, it is especially charged, with the pressures of contemporary culture and modern technology (Waddell, 2018), being selfdetermined is a developmental task that all young people must confront and is pertinent to their whole-person development.

Self-Determination Theory (SDT) of motivations (Deci \& Ryan, 2000; Ryan \& Deci, 2017) proposes that motivation is the result of fulfilling varying levels of psychological needs. This variation can be conceptualized along a continuum comprised of five typologies: amotivation, external regulation, introjected regulation, identified regulation, and intrinsic motivation. The desired type of study motivation is intrinsic motivation, as it is associated with deep learning, better performance, and positive well-being compared to others. Numerous investigators have applied the (SDT) framework to intrinsic motivation in educational contexts (Niemiec \& Ryan, 2009). Intrinsic motivation is observed when one engages in an activity out of own interest and is truly self-determined. It is dependent on the fulfilment of three basic psychological needs described by (SDT). These are the needs for autonomy, competence, and relatedness. In a review of (SDT) applications to educational practice (Deci \& Ryan, 1987; Silvia, 2008; Tsai et al., 2008), they suggest that both intrinsic motivation and autonomous types of extrinsic motivation are conducive to engagement and optimal learning in educational contexts. Psychological well-being can be predicted by the degree of satisfaction of three basic psychological needs.

According to (SDT), autonomy-supportive teaching is important, because it makes students feel autonomous and competent in their learning and supported (relatedness) by their teachers. Within (SDT), for an individual to become self-determined (intrinsically motivated) all three of their psychological needs (autonomy, competence, and relatedness) must be fulfilled. Autonomy is, together with competence and relatedness, conceived as a fundamental and universal psychological need, the satisfaction of which is conducive to individuals' well-being and quality of life (Collie, Shapka, Perry, \& Martin, 2016). Autonomy represents an inner endorsement of one's actions- the sense that one's actions emanate from oneself and are one's own (Burton et al., 2006). Giving students time to work on a problem in their own way is an autonomy-supportive behavior because the teacher allows students' interests and preferences to guide their classroom activity. Overall, autonomy support revolves around finding ways to nurture, support, and increase students' inner endorsement of their classroom activity (Patall, 2013; Patall, Cooper \& Wynn, 2010; Vansteenkiste \& Ryan, 2013) and fostering dependent relationships between themselves and the students (Haerens et al., 2019). In parallel, the interpersonal styles of the teacher who participate in the motivational regulations of the students can be conceptualized as autonomy support (Reeve, 2016). Moreno-Murcia et al., (2018), in a study with adolescents (13 to 19 years old) checked the prediction capacity of teacher's autonomy support in physical education and its results revealed positive and significant relationships between support for autonomy that positively predicted the satisfaction of needs. basic psychological, and this, in turn, predicted self-determined motivation, which predicted fun. The fun predicted the importance given to physical education, and it the intention to be physically active, which finally predicted the usual physical activity rate (Moreno-Murcia et al., 2018). In this sense, the classroom climate generated by the teacher through a certain methodology can have great relevance regarding the intention of being physically active (Cabello, Moyano \& Tabernero, 2018; 
Fierro-Suero, Velázquez-Ahumada \& Fernández-Espínola, 2021).

The characteristics of the subject of physical education, defined by the National Association for Sport and Physical Education (NASPE) make it a remarkable subject, provided that adequate didactic conditions are ensured. «A high-quality physical education program enables students to develop motor skills, understand movement concepts, participate in regular physical activity, maintain healthy fitness levels, develop responsible personal and social behavior, and value physical activity». Physical education learning, as a subject where its contents are mainly practical, may have seen their student's progress, in terms of skill execution and overall sport performance, compromised. Learning competence, defined by The European Commission in 2005 as «the disposition and ability to initiate and continue one's own learning, to regulate this learning, and to manage one's time and information effectively, both individually and within a group», refers to the acquisition, selection and integrated mobilization of the knowledge, attitudes and skills. It requires for continuous learning, and it is essential for people who must function effectively and manage these days (Villardón-Gallego et al. 2013). Several studies have deep in the way to measure learning competence such as learning styles (López-Aguado, 2010), the self-management of learning (Solzbacher, 2006), learning strategies (Gargallo, SuárezRodríguez \& Pérez-Pérez, 2009) and performance (García-Ros \& Pérez- González, 2011). However, all of them showed certain confusion in relation to the concept. The Learning Competence Scale (LCS) proposed by Villardón-Gallego et al. (2013) explains a general dimension that would refer to the construct named learning competence, may be an ideal tool for that matter.

Teachers need to develop various facets of classroom competence and wider professional competence in order to perform professional tasks in right situations of learning (Van Dinther, Dochy, Segers \& Braeken, 2013; Fernández-Villarino, Toja-Reboredo \& GonzálezValeiro, 2021; Furlong et al., 1988; Pantic \& Wubbels, 2010; Rodriguez, DelValle \& De laVega, 2018; Struyven \& De Meyst, 2010). Professional competence as a broadly conceived integrated set of knowledge and understanding, skills and abilities, and teachers' beliefs and values. To teach encompasses learning how to deal with social and cultural working conditions in schools plus the technical endeavor of acquiring professional knowledge and developing effective teaching skills (Rots,
Kelchtermans \& Aelterman, 2012). In addition, competence and autonomy need satisfaction is associated with greater job satisfaction and commitment to their school of employment (Lee and Nie, 2014).

We focus on the role of the teacher generating intrinsic motivation in students and the methodology as a key element of the organizational dimension of the teacher's work in student learning (Krech, Kulinna, Cothran, 2010). In contrast with university field, where educative excellence through diverse ways is sought, high school teachers are not commonly evaluated by the students through questionnaires that guarantee a good internal consistency of the teaching-learning process (Baena-Extremera, Granero-Gallegos \& MartínezMolina, 2015). This is even lesser common in physical education lessons, which has a quite different educative process compared with other areas of knowledge carried into the classrooms. In addition, it is necessary to remark the importance that area has in the integral formation of the students, even more in the promotion of physical activity and healthy lifestyle beyond the scholar schedule among teenagers (Cádiz et al., 2021; Stratton, Fairclough \& Ridgers, 2008). Considering all of that, it seems to be primordial to analyze teacher's role (the relationship that the teacher generates with the students) and methodology as a key element of the learning in quarantine.

In the sections to follow, we outline the methods used to guide our study, including detailed discussion of our analytic process and how we worked to ensure trustworthiness of these analyses. We then share a model of learning and a detailed discussion of our findings in quarantine. Finally, we examine how our findings support and advance current literature regarding how physical education learning can be modulate by (SDT) experiences and the teacher's competence and their implications for education.

\section{Methods}

\section{Design}

The present study is a quick, large cross-sectional online survey realized through Google Forms web survey platform (Google LLC, Mountain View, CA, United States). The online survey was communicated as via official channels of the Education high school.Via e-mails, it was shared to personal contacts of the research group members and of the high school students. Before starting the questionnaire, the online survey, totally anonymous and not traceable to identity of participants, 
including a brief description of the study, its aim, and began in Spain by 17 regions at 15th of June 2020:

https: / / docs.google.com/forms/d/e / 1 FAIpQLScKidVkm Po6mghcx X2 Pa WacjbqPufo0_52Cp_gE9tiMGYElg/viewform?usp=sf_link

Anonymity and confidentiality as follow: «The data of this survey are anonymous, confidential and their confidentiality will be guaranteed. We remind you that participation is voluntary and therefore, can withdraw or renounce at any time. The participant, informed according to the methods and purposes of the research described above, expresses his/her consent to his/her participation, having the guarantee that his/her personal data will be processed anonymously. All subjects participating in the online survey gave their informed consent before participation. The study was approved by the ethics committee of the Autonomous University of Madrid (registration No. CEI-106-2060), and it was conducted in accordance with the Declaration of Helsinki.

\section{Participants}

A total of 686 Spanish students' high school of different social classes and level of instruction completed the online Google form questionnaire over a period of 16 days (from June 15-31, 2020) during COVID-19 emergency in Spain. To minimize the impact of errors, a cleaning process was adopted in order to remove ineligible cases identify meaningless data, representing invalid questionnaire responses due to the unwillingness of the participant to provide a valid response according to American Association for Public Opinion Research addressed in «Standard Definitions». Then, the sample comprised 686 high school students' 297 (43.23\%) male and 390 (56.67\%) women. They averaged 12-18 years old. The men varied in age from 11.5 to 19.3 years old, and the women varied in age from 11.80 to 19.20 years old.

\section{Questionnaire}

The online questionnaire administered to the participants included a copy of the institutionally approved informed consent form prior to the scheduled questionnaire:

https: / / docs.google.com/forms/d/e / 1 FA IpQLScKidVkm Po 6 m ghcx X 2 Pa WacjbqPufo0_52Cp_gE9 tiMGYElg/viewform?usp=sf_link

Upon our scheduled questionnaire, all participants reviewed the informed consent form and agreed to participate (respondents below the age of 16, according to APA guidelines, the parents of these participants approved the informed consent too). Participants were answer one time at the end of the month for $<_{\ll 15^{\prime}}$. The questionnaire structure was based on Villardón-Gallego et al., (2013), Moreno-Murcia, González-Cutre, Chillón, y Parra (2008) and Baena-Extremera, Granero-Gallegos \& Martínez-Molina (2015). 38 questions focused on the participants' experiences of learning on physical education program, (SDT) and teaching-learning process, during COVID-19 emergency (last three months of the academic course). The first scale Learning Competence Scale (LCS) Villardón-Gallego et al., (2013), centered around physical education learning program and experiences in the program $(\mathrm{GFI}=.94$, RMSEA=.039). Four categories: Knowledge Transfer (KT); self-knowledge as apprenticeship (SKA); construction of Knowledge (CK); self-management of learning (SML). Participants reported 18 questions of different types of responses, i.e., 10. During confinement, I can recognize basic material for physical education on the Internet. 14. During confinement I keep trying when performing difficult or uninteresting tasks related to physical education. 17. During confinement I modify my learning strategies in physical education if they do not meet my expectations. Likert Scale 1-5 (strongly disagree-strongly agree). The second focused Basic Psychological Needs in Exercise Scale (BPNES) Moreno-Murcia et al. (2008), (GFI=.94; RMSEA =.07); Three categories: competence $(C)$, autonomy (A) and relatedness (R). Participants reported 12 questions of different types of responses, i.e., 1. During confinement, the exercises that I have carried out have been adjusted to my interests; 3. During confinement I have felt very comfortable when I have done physical exercise like the other colleagues; 5. During confinement I have performed effective physical exercise; 7. During confinement, the way of performing the physical exercises has responded to my wishes. Likert Scale 1-5 (strongly disagree-strongly agree). The third on the teaching Competencies (ETCS) BaenaExtremera, et al. (2015) to support the physical education learning $(\mathrm{GFI}=.99$, RMSEA=.023). Eight categories: Communication, Work awareness, creativity, Feedback, individual consideration to the teacher, professionalism, problem solving, social awareness, but we were interested in the total score. Participants reported 8 questions of different types of responses, i.e., 3. Has the physical education teacher been creative during confinement? 5. Had the physical education teacher had during the confinement individual 
knowledge of you? 7. Has the physical education teacher resolved the problems during confinement? Likert Scale 1-7 (very little-a lot).

\section{Statistical analysis}

Statistical analysis was performed using IBM ${ }^{\circledR}$ SPSS Statistics version 21.0 software. To determine the best predictor of learning competence in physical education, mediated for teacher's competencies and the basic psychological needs in exercise, four multiple linear regression were performed for each subscale of the LCS. The mediation models were conducted to test «simultaneous mediation by multiple variables» (Preacher \& Hayes, 2008, p. 880). Four parallel mediation models were examined: First, the relationship between Knowledge Transfer (KT) and ETCS as mediated by (C), (A) and (R), second, the relationship between self-knowledge as apprenticeship (SKA) and ETCS as mediated by (A) and (R); third, the relationship between construction of Knowledge (CK) and ETCS as mediated by (A) and (R); fourth the relationship between self-management of learning (SML) and ETCS as mediated by (A) and (R). For all models, total and specific indirect effects were examined. Concerning conserving the greater statistical power for this test, without assuming multivariate normality in the sampling distribution, bootstrap analysis was used to test the significance of the indirect effects (Mallinckrodt, Abraham, Wei, \& Russell, 2006; Preacher \& Hayes, 2008).

\section{Results}

Baseline characteristics of the study subjects are displayed in Table 1. Overall, the study sample $(n=686)$ comprised 297 (43.23\%) male and 390 (56.67\%) women. They averaged $12-18$ years old. The men varied in age from 11.5 to 19.3 years old, and the women varied in age from 11.80 to 19.20 years old. A summary of descriptive statistics is provided in Table 1.

\begin{tabular}{lcccc}
$\begin{array}{l}\text { Table 1. } \\
\text { Descriptive análisis. }\end{array}$ & \multicolumn{5}{l}{} \\
\hline & Mean & Standard Deviation & Skewness & Kurtosis \\
\hline ETCS & 5.36 & 1.39 & -1.01 & 0.50 \\
A & 3.60 & 0.98 & -0.58 & -0.23 \\
C & 3.74 & 0.94 & -0.65 & -0.01 \\
R & 3.74 & 1.00 & -0.75 & -0.01 \\
LCS_KT & 3.07 & 1.16 & -0.19 & -0.89 \\
LCS_SKA & 3.80 & 0.85 & -0.91 & 0.86 \\
LCS_Ck & 4.02 & 0.87 & -1.11 & 1.16 \\
LCS_SML & 3.72 & 0.82 & -0.53 & -0.05 \\
\hline
\end{tabular}

The Participants had to give information about the physical education learning program (during the COVID-19 quarantine), several variables like motivation because of fulfilling varying levels of psychological needs or the teaching-learning process were involved. Multiple linear regression explanatory variables to predict the outcome of a response variable. Results of Multiple linear regression is shown in Table 2.

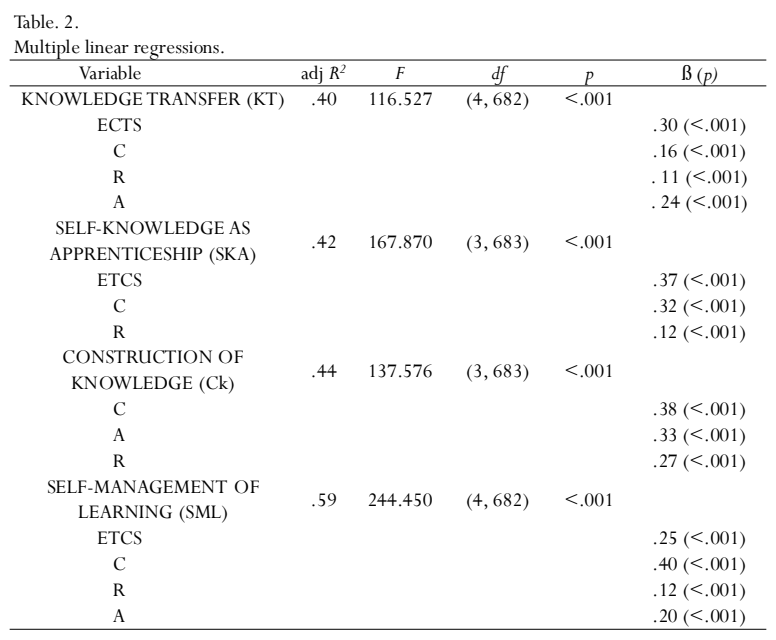

ETC is a significant predictor of $\mathrm{KT}(\mathrm{b}=.42$, s.e. $=$ $.02, \mathrm{p}<.001)$. This coefficient reflects the direct effect of ETC on KT, the c path in the model. ETCS is a sign.

To delve into the topic, it is necessary to ask what relationship the variables have with each other to identify and explain the mechanism or process that underlies an observed relationship between an independent variable (LCS) and a dependent variable (ETCS) via the inclusion of a third hypothetical variable, known as a mediator variable $(\mathrm{C}, \mathrm{A}, \mathrm{R})$. Rather than a direct causal relationship between the independent variable and the dependent variable, a mediation model proposes that the independent variable influences the (non-observable) mediator variable, which in turn influences the dependent variable. Thus, the mediator variable serves to clarify the nature of the relationship between the independent and dependent variables. Mediation analyses are employed to understand a known relationship by exploring the underlying mechanism or process by which one variable influences another variable through a mediator variable.

Four mediation models were performed. The difference among them is the outcome, so the initial relationships from ETCS to the mediators will only be described the first time. First model, the relationship between knowledge transfer (KT) and Evaluation of Teaching Competencies Scale (ETCS) as mediated by competence $(\mathrm{C})$, autonomy $(\mathrm{A})$ and relatedness $(\mathrm{R})$, we observe ETC was a significant predictor of $\mathrm{KT}(\mathrm{b}=$ .42 , s.e. $=.02, p<.001)$. This coefficient reflects the direct effect of ETCS on KT, the «C» path in the model. 
Regardless the three mediators: ETCS was a significant predictor of $\mathrm{C},(\mathrm{b}=.28$, s.e. $=.02, p<.001)$. The standardized regression coefficient for this path is .42 . ETCS was a significant predictor of $\mathrm{R},(\mathrm{b}=.25$, s.e. $=$ $.02, p<.001)$. The standardized regression coefficient for this path was .35 . ETCS was a significant predictor of PNA $(b=.30$, s.e. $=.02, p<.001)$. The standardized regression coefficient for this path is .42 . The total indirect effect was significant (.17, CI [.13, .21]). See Figure 1.

Second model, the relationship between selfknowledge as apprenticeship (SKA) and ETCS as mediated by (A) and (R). In the SKA mediation model ETC was a significant predictor of SKA $(b=.34$, s.e. $=$ $.02, p<.001)$; also, the total indirect effect was significant $(.09$, CI [.06, .12]). See Figure 2.

Third model, the relationship between construction of Knowledge (CK) and ETCS as mediated by (A) and (R). In the CK mediation model ETC was a significant predictor of CK $(b=.36$, s.e. $=.02, p<.001)$; also, the total indirect effect was significant (.09, CI [.06, .13]). See Figure 3.

Fourth model, the relationship between selfmanagement of learning (SML) and ETCS as mediated by (A) and (R). In the SML mediation model ETC was a significant predictor of SML $(b=.32$, s.e. $=.02, p<$
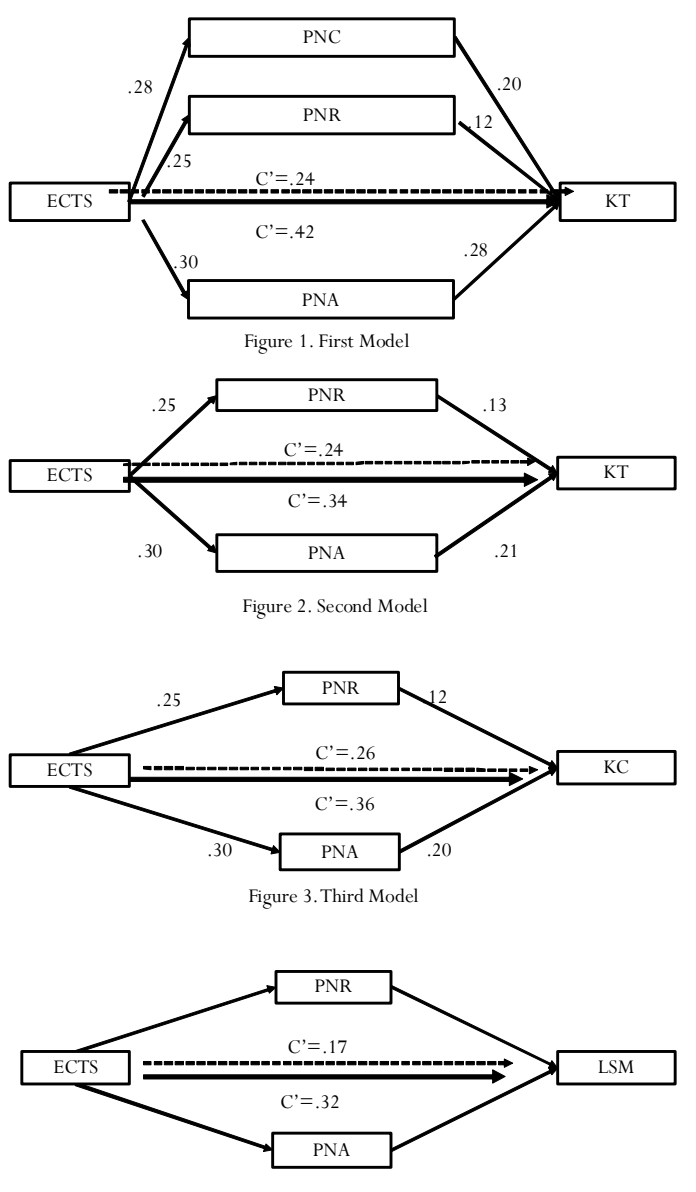

Figure 4. Fourth Model
$.001)$; also, the total indirect effect was significant (.14, CI $[.11, .18])$. See Figure 4 .

For all models, total and specific indirect effects were examined.

\section{Discussion}

This study adds new knowledge to the field of physical education learning by providing empirical findings regarding two under-researched issues. First, it extends our understanding of the relationship between learn the Spanish high school-curriculum in physical education in quarantine, teachers' competence and students' motivation to perform tasks attending relationship with society's demands. Second, the findings of four relationship models show how in quarantine, a significant predictor, in the relationship between learning physical education competence (knowledge transfer, knowledge as an apprentice, construction of Knowledge and learning self-management), is teachers' competence mediated by students' motivation (psychological needs: competence, autonomy and relatedness).

The findings of the study need to be interpreted in the light of the two major limitations of the study. First, the study examined students' perceptual data without independent measures of teachers' professional competence. Second, the study only examined perception of learning competence on Spanish high school curriculum of physical education. Caution is needed when generalizing findings to other settings. What follows is a discussion of the findings of this study and their implications for education.

\section{Teachers" competence and students' motivation}

Analyzing first issue, relationship between the learn, teachers' competence and students' motivation to perform tasks attending relationship with society's demands. Scientific literature pays relatively less attention to the organizational dimension of teachers' work in student' learning as revealed in the qualitative findings of the study (Rodriguez et al., 2018; Tang, Wong \& Cheng, 2016). This calls for more learning opportunities to be provided for student teachers to learn about the organizational dimension of teachers' work plus relationships themselves and the students, which we shall discuss in greater detail in the next section.

Looked at the needs for competence (Lee and Nie, 2014) indicated that competence need satisfaction among 
teachers meant they were more likely to be satisfied with their jobs and committed to the profession of teaching (i.e., professional commitment). Where we could fine organizational dimension of teachers' work in student' learning. Teachers with a high sense of efficacy tend to be more open-minded, more willing to implement new teaching strategies, more apt to develop challenging materials, more likely to persist when students are having problems, and more likely to address students' individual needs than the teachers with a weaker sense of efficacy (Allinder 1994; Ashton and Webb 1986; Fuchs et al., 1992; Guskey 1988; Stein and Wang 1988; Tschannen-Moran et al. 1998; VillaverdeCaramés et al., 2021). Also, a higher teacher competence must contain qualities such as availability, communication, conscientiousness, creativity, feedback, individual consideration, professionalism, problemsolving, and social awareness (Granero-Gallegos \& Baena-Extremera, 2016; Krech, Kulinna \& Cothran, 2010). Highlighting teacher's role and methodology as a key element of the organizational dimension of teachers' work in student' learning.

Collie, Shapka, Perry, and Martin (2016) demonstrated that basic psychological need satisfaction was associated with greater autonomous motivation, work-related well-being, job satisfaction, and organizational commitment. Notably, the different basic psychological needs played differing roles in predicting these outcomes. (SDT) is a relevant framework for helping to understand teachers' experiences at work and how these can affect students. Teachers should adopt more flexible attitudes towards their students and be more open to understanding their feelings and desires (Patall, 2013), giving them more opportunities to perform tasks (Patall, Cooper \& Wynn, 2010), using more positive language and inviting them to perform tasks (Vansteenkiste \& Ryan, 2013), and fostering dependent relationships between themselves and the students (Haerens \& colleagues, 2019).

Higher teacher competence is also more likely to utilize teaching strategies that support students' basic psychological need satisfaction (Taylor, Ntoumanis, \& Standage, 2008). This is known as autonomy-supportive teaching, and it helps to create an optimal learning environment for students. When teachers are autonomysupportive, they teach in ways that help to promote students' volition and choice, and support students' internalization of school and classroom values and norms, while also minimizing pressure or control from the teacher, applicable in physical education.
Reeve and Jang (2006) identified several teaching behaviors that are indicative of autonomy-supportive teaching. These include the time that teachers spend listening and allowing students to work in their own way and the time that students spend talking. In all cases, the more time teachers allowed students to work on their own and talk amongst themselves, the more autonomy-supportive this was for students. Teachers' use of praise as informational feedback, encouragement, and hints to help students solve problems or complete their work are also autonomy supportive. Also being responsive to student generated questions and acknowledging students' perspectives are teaching behaviors associated with autonomy-support. More precisely, autonomy-supportive teaching strategies help students to experience autonomy through, for example, the choice and control offered to students, the competence developed via effective teacher feedback, and the relatedness nurtured through a respectful classroom environment (Reeve, Bolt, \& Cai, 1999; Reeve \& Cheon, 2014). Teachers who report having low autonomy at work (i.e., those who report that they lack the autonomy to influence school policy and/or to choose how and what they teach, and/or those who perceive those administrative duties and paperwork interfere with their teaching) are less likely to support their students' need for autonomy compared to teachers who report having higher autonomy at work (Marshick et al., 2016).

Standage, Taylor, and Ntoumanis (2005) conducted a study among UK school students and found that when teachers were perceived to be autonomy-supportive, students were more likely to experience a sense of autonomy, competence, and relatedness. In turn, they were also more likely to be autonomously motivated for their learning. Haerens et al., (2015) among a sample of Belgian secondary school students, they found that when students perceived their teacher to be autonomysupportive, they felt a sense of autonomy, competence, and relatedness, and tended to be more autonomously motivated. If amotivation can be controlled or minimized by the teachers and, at the same time, intrinsic motivation is properly fostered, student commitment can lead to the desired learning of the contents proposed in the class (Aelterman et al., 2014; Den Berghe et al., 2012). The intrinsic motivation of the students should be positively channeled to meet their needs and to enhance them in a way that arouses their interest and curiosity for achieving a desired goal (Ryan \& Deci, 2017). 
Thus, the interrelationship between teachers' and students' experiences in the classroom. When classrooms and schools promote autonomy, competence, and relatedness among all members, this has the potential to yield beneficial outcomes for teaching and learning an implication relevant to researchers, teachers, and educational leaders looking to improve school effectiveness (Ashton \& Webb, 1986; Collie \& Martin, 2015; Goddard et al. 2000; Midgley et al. 1989; Woolfolk et al., 1990). Considerable research suggests that students work harder, feel more engaged and connected to school, are more intrinsically motivated, and achieve academically at higher levels when they believe that their teachers understand and care about them (Chang et al. 1981; Furrer and Skinner 2003; McAllister and Irvine 2002; Solomon et al., 2000). Moreover, children in classrooms with teachers who use autonomysupportive strategies tend to have higher intrinsic motivation, perceived competence, engagement, and self-esteem than children in classrooms of teachers who use more controlling strategies (Cádiz et al., 2021; Cheon \& Reeve 2015; Deci et al. 1981a, b; Guay \&Vallerand 1996). These findings are important for physical education because the classroom climate generated by the teacher plus a certain methodology can have great relevance regarding the intention of being physically active (Cabello et al., 2018; Moreno-Murcia et al., 2018; Fierro-Suero et al., 2021), fundamental aspect in the pandemic because you are closed at home and the classes are not face-to-face.

\section{Physical education in confinement}

Analyzing second issue, scientific literature pays less attention to the organizational dimension of student' learning competence, in physical education in quarantine. The qualitative findings of the study reveals are notably the different basic psychological needs played different roles in predicting learning competence mediated by teachers'. Learning competence in physical education requires for continuous learning and it is essential for people who must function effectively and manage the situations (Villardón-Gallego et al., 2013; VillaverdeCaramés et al., 2021), more in pandemic (Burgueño et al., 2021). Thus, the knowledge transfer in learning has a direct relationship with teacher' competence mediated by three basic psychological needs: competence, autonomy, and relatedness, (Ashton \& Webb 1986; Collie \& Martin, 2015; Goddard et al., 2000; Midgley et al., 1989; Woolfolk et al., 1990). Also, teachers' competence was a significant predictor of the relationship between self-knowledge as apprenticeship, construction of Knowledge and learning self-management, mediated by autonomy and relatedness. This study shows the importance of autonomy (Reeve, Bolt, \& Cai, 1999; Reeve \& Cheon, 2014), and relatedness (Haerens et al., 2019) over competence in the students' perception of learning competence in physical education in quarantine, mediated by teachers' competence. If we analyze the models finding, knowledge transfer is the most significant indicator over the self-knowledge as apprenticeship, construction of Knowledge and selfmanagement of learning directly related with teachers' competence and mediated by three basic psychological needs (competence, autonomy, and relatedness). It seems that we must pay attention to how the transfer of knowledge occurs because it is the most significant indicator in the relationship established by the competent teacher as a long as the teacher develops the three basic needs of the students.

\section{Conclusion}

This study reveals that teacher competence is a significant predictor of learning physical education mediated by psychological needs during the pandemic. Students' beliefs about success in physical education have a limited influence on the teachers' competence and knowing how to attend to the basic psychological needs of the students.

The transfer of knowledge is a significant indicator over the self-knowledge as apprenticeship, construction of Knowledge and self-management of learning directly related with teachers' competence and mediated by three basic psychological needs (competence, autonomy, and relatedness). The question we ask ourselves is if this would happen in attendance to face-to-face class in physical education.

\section{Data Availability Statement}

The datasets generated for this study are available on request to the corresponding author.

\section{Ethics Statement}

The studies involving human participants were reviewed and approved by Research Ethics Board of Autonomous University of Madrid. The patients/ participants provided their written informed consent to participate in this study. 


\section{Conflict of interests}

The authors declare that the research was conducted in the absence of any commercial or financial relationships that could be construed as a potential conflict of interest.

\section{Author Contributions}

All authors listed have made a substantial, direct, and intellectual contribution to the work, and approved it for publication.

\section{References}

Aelterman, N., Vansteenkiste, M., den Berghe, L., De Meyer, J., Haerens, L. (2014). Fostering a NeedSupportive Teaching Style: Intervention Effects on Physical Education Teachers' Beliefs and Teaching Behaviors. J. Sport Exerc. Psychol., 36, 595-609. DOI: 10.1123/jsep.2013-0229

Allinder, R. M. (1994).The relationship between efficacy and the instructional practices of special education teachers and consultants. Teacher Education and Special Education, 17, 86-95.

Ashton, P.T., \&Webb, R. B. (1986). Making a difference: Teachers' sense of efficacy and student achievement. New York: Longman.

Baena-Extremera, A., Granero-Gallegos, A. \& MartínezMolina, M. (2015). Spanish version of the Evaluation of Teaching Competencies Scale in Physical Education of secondary school. Cuadernos de Psicología del Deporte, 15(3), 113-122.

Boletín Oficial del Estado núm. 67, de 14 de marzo de 2020, páginas 25390-25400. Sección I. Disposiciones generales. Disponible en: https: / / www.boe.es/eli/ es/rd/2020/03/14/463. Consultado 9 Jul 2020.

Burgueño, R., Bonet-Medina, A., Cerván-Cantón, A., Espejo, R., Fernández-Berguillo, F.B., Gordo-Ruiz, F., Linares-Martínez, H., Montenegro-Lozano, S., Ordoñez-Tejero, N., Vergara-Luque, J.J., Gil-Espinosa, F.J. (2021). Educación Física en Casa de Calidad. Propuesta de aplicación curricular en Educación Secundaria Obligatoria. Retos, 39, 787-793. https://doi.org/10.47197/retos.v0i39.78792.

Burton, K.D., Lydon, J.E., D’Alessandro, D.U. and Koestner, R. (2006) 'The differential effects of intrinsic and identified motivation on well-being and performance: Prospective, experimental, and implicit approaches to selfdetermination theory'.
Journal of Personality and Social Psychology 91:75062.

Cabello, A., Moyano, M., Tabernero, C. (2018). Procesos psicosociales en Educación Física: actitudes, estrategias y clima motivacional percibido. Retos, 34, 19-24. https://doi.org/10.47197/ retos.v0i34.57668.

Cádiz, P., Barrio, L.A., León, D., Hernández, A., Milla, M., Sotomayor, M. (2021). Motivación contextual desde la autodeterminación en las clases de Educación Física. Retos, 41, 88-94. https://doi.org/ 10.47197/retos.v0i41.80998.

Chang, A. F., Berger, S. E., \& Chang, B. (1981). The relationship of student self-esteem and teacher empathy to classroom learning. A Quarterly Journal of Human Behavior, 18(4), 21-25.

Chen, P.; Mao, L.; Nassis, G.P.; Harmer, P.; Ainsworth, B.E.; Li, F. (2020). Coronavirus disease (COVID19). The need to maintain regular physical activity while taking precautions. J. Sport. Heal. Sci. 9, 103104.

Cheon, S. H., \& Reeve, J. (2015). A classroom-based intervention to help teachers decrease students' amotivation. Contemporary Educational Psychology, 40, 99-111.

Collie, R.J., \& Martin, A.J., (2015). Teachers' psychological needs, motivation, and autonomysupport: Impacts on students' growth goals and achievement outcomes. In B. Higgins (Ed). Goal setting and personal development: Teachers' perspectives, behavioral strategies, and impact on performance. New York: Nova Science Publishers.

Collie, R.J., Shapka, J.D., Perry, N.E., \& Martin, A.J. (2016). Teachers' psychological functioning in the workplace: Exploring the roles of contextual beliefs, need satisfaction, and personal characteristics. Journal of Educational Psychology, 108, 788-799. DOI: 10.1037/edu0000088.

Deci, E. L., \& Ryan, R. M. (1987). The support of autonomy and the control of behavior. Journal of Personality and Social Psychology, 53, 1024-1037.

Deci, E. L., Nezlek, J., \& Sheinman, L. (1981a). Characteristics of the rewarder and intrinsic motivation of the rewardee. Journal of Personality and Social Psychology, 40, 1-10.

Deci, E. L., Schwartz, A. J., Sheinman, L., \& Ryan, R. M. (1981b). An instrument to assess adults' orientations toward control versus autonomy with children: Reflections on intrinsic motivation and perceived competence. Journal of Educational 
Psychology, 73, 642-650.

Deci, E.L. \& Ryan, R.M. (2000)The «What» and «Why» of Goal Pursuits: Human Needs and the SelfDetermination of Behavior. Psychological Inquiry 11(4), 227-268.

Den Berghe, L.; Vansteenkiste, M.; Cardon, G.; Kirk, D.; Haerens, L. (2012). Research on selfdetermination in physical education: Key findings and proposals for future research. Phys. Educ. Sport Pedagog., 19, 97-121. DOI: 10.1080/ 17408989.2012 .732563

European Commission (2001). Making a European area of lifelong learning a reality. Brussels. Retrieved from http:/ /www.bologna-berlin2003.de/pdf/ MitteilungEng.pdf

Fierro-Suero, S., Velázquez-Ahumada, N., FernándezEspínola, C. (2021). La influencia del clima de aula sobre las emociones del alumnado. Retos, 42, 434442. DOI: https://doi.org/10.47197/ retos.v42i0.87305.

Fuchs, L. S., Fuchs, D., \& Bishop, N. (1992). Instructional adaptation for students at risk. Journal of Educational Research, 86, 70-84.

Furlong, J., Hirst, P., Pocklington, K., \& Miles, S. (1988). Initial teacher training and the role of the school. Buckingham: Open University Press.

Furrer, C., \& Skinner, E. (2003). Sense of relatedness as a factor in children's academic engagement and performance. Journal of Educational Psychology, 95(1), 148-162.

García-Ros, R., \& Pérez-González, F. (2011). Validez predictiva e incremental de las habilidades de autorregulación sobre el éxito académico en la universidad. Revista de Psicodidáctica, 16(2), 231-250.

Gargallo, B., Suárez-Rodríguez, J. M., \& Pérez-Pérez, C. (2009). El cuestionario CEVEAPEU. Un instrumento para la evaluación de las estrategias de aprendizaje de los estudiantes universitarios. RELIEVE, 15, 2. Retrieved from http://www.uv.es/RELIEVE/v15n2/RELIEVE v15n2_5.htm

Goddard, R. D., Hoy,W. K., \& Woolfolk-Hoy,A. (2000). Collective teacher efficacy: Its meaning, measure, and impact on student achievement. American Educational Research Journal, 37, 479-507

Granero-Gallegos, A., Baena-Extremera, A. (2016). Validación española de la versión corta del Physical Education Classroom Instrument para la medición de conductas disruptivas en alumnado de secundaria. CDP, 16, 89-98.: https:// www.researchgate.net/publication/304111775
Guay, F., \& Vallerand, R. J. (1996). Social context, student's motivation, and academic achievement: Toward a process model. Social Psychology of Education, 1(3), 211-233.

Guskey, T. R. (1988). Teacher efficacy, self-concept, and attitudes toward the implementation of instructional innovation. Teaching and Teacher Education, 4(1), 6369.

Haerens, L., Aelterman, N., Vansteenkiste, M., Soenens, B., \& Van Petegem, S. (2015). Do perceived autonomy-supportive and controlling teaching relate to physical education students' motivational experiences through unique pathways? Distinguishing between the bright and dark side of motivation. Psychology of Sport and Exercise. 16(Part 3), 2636. http://dx.doi.org/10.1016/ j.psychsport.2014.08.013

Haerens, L.; Krijgsman, C.; Mouratidis, A.; Borghouts, L.; Cardon, G.; Aelterman, N. (2019). How does knowledge about the criteria for an upcoming test relate to adolescents' situational motivation in physical education? A self-determination theory approach. Eur. Phys. Educ. Rev., 25, 983-1001. https://doi.org/10.1177/1356336X18783983

Huang, R.H., Liu, D.J., Tlili, A., Yang, J.F., Wang, H.H., et al. (2020). Handbook on Facilitating Flexible Learning During Educational Disruption: The Chinese Experience in Maintaining Undisrupted Learning in COVID-19 Outbreak. Beijing: Smart Learning Institute of Beijing Normal University.

Krech, P.R.; Kulinna, P., Cothran, D. (2010). Development of a short-form version of the Physical Education Classroom Instrument: Measuring secondary pupils' disruptive behaviours. Phys. Educ. Sport Pedagog., 15, 209-225. https://doi.org/ 10.1080/17408980903150121

Lee, A. N., \& Nie, Y. (2014). Understanding teacher empowerment: Teachers' perceptions of principal's and immediate supervisor's empowering behaviours, psychological empowerment and work-related outcomes. Teaching and Teacher Education, 41, 6779. http://dx.doi.org/10.1016/j.tate.2014.03.006 López-Aguado, M. (2010). Diseño y análisis del Cuestionario de Estrategias deTrabajo Autónomo (CETA) para estudiantes universitarios. Revista de Psicodidáctica, 15(1), 77-99

Mallinckrodt, B., Abraham, W. T., Wei, M., \& Russell, D. W. (2006). Advances in testing the statistical significance of mediation effects. Journal of Counseling Psychology, 53(3), 372-378. 
doi:10.1037/0022-0167.53.3.372

Marshik, T., Ashton, P.T. \& Algina, J. Teachers' and students' needs for autonomy, competence, and relatedness as predictors of students' achievement. Soc Psychol Educ 20, 39-67(2017). https: / /doi.org / $10.1007 / \mathrm{s} 11218-016-9360-\mathrm{z}$

McAllister, G., \& Irvine, J. J. (2002). The role of empathy in teaching culturally diverse students: A qualitative study of teachers' beliefs. Journal of Teacher Education, 53(5), 433-443.

Midgley, C., Feldlaufer, H., \& Eccles, J. (1989). Student/ teacher relations and attitudes toward mathematics before and after the transition to junior high school. Child Development, 60, 981-992

Moreno-Murcia, J.A., González-Cutre, C., Chillón, M., \& Parra, N. (2008). Adaptación a la educación física de la escala de las necesidades psicológicas básicas en el ejercicio. Revista Mexicana de Psicología, Vol. 25, 2, 295-303.

Moreno-Murcia, J.A., Huéscar, E. \& Ruíz, L. (2018). Capacidad predictiva del apoyo a la autonomía en clases de educación física sobre el ejercicio físico. Revista Latinoamericana de Psicología 51(1), 30-37 Doi: http://dx.doi.org/10.14349/ rlp.2019.v51.n1.4

National Association for Sport and Physical Education (2008). Comprehensive School Physical Activity Programs. Reston, VA: National Association for Sport and Physical Education.

Niemiec, C.P. \& Ryan, R.M. (2009). Autonomy, competence, and relatedness in the classroom Applying self-determination theory to educational practice. Theory and Research in Education. Vol 7(2) 133-144 ISSN 1477-8785 DOI: 10.1177/ 1477878509104318

Pantic, N. \& Wubbels, T. (2010). Teacher competencies as a basis for teacher education - Views of Serbian teachers and teacher educators. Teaching andTeacher Education. 26. 694-703. Doi: 10.1016/ j.tate.2009.10.005.

Patall, E.A. (2013). Constructing motivation through choice, interest, and interestingness. J. Educ. Psychol., 105, 522-534. DOI: 10.1037/a0030307

Patall, E.A.; Cooper, H.; Wynn, S.R. (2010). The effectiveness and relative importance of choice in the classroom. J. Educ. Psychol., 102, 896-915.DOI: $10.1037 / \mathrm{a} 0019545$

Preacher, K. J., \& Hayes, A. F. (2008). Asymptotic and resamplingstrategies for assessing and comparing indirect effects in multiple mediator models.
Behavior Research Methods, 40, 879- 891. https: /

/ www.researchgate.net/publication /

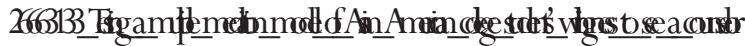
[accessed Oct 24 2020].

Reeve J. (2016). Autonomy-suppoprtive teaching: What it is, how to do it In Building autonomus learners. Perspectives from research and practice using selfdetermination theory. Singapore: Springer.

Reeve, J. \& Cheon, S.H. (2014). An Intervention-Based Program of Research on Teachers' Motivating Styles, Motivational Interventions. Advances in Motivation and Achievement, 18, 293-339. https://doi.org/ 10.1108/S0749-742320140000018008

Reeve, J., \& Jang, H. (2006). What teachers say and do to support students' autonomy during a learning activity. Journal of Educational Psychology, 98, 209. 218. http://dx.doi.org/10.1037/00220663.98.1.209

Reeve, J., Bolt, E., \& Cai, Y. (1999). Autonomysupportive teachers: How they teach and motivate students. Journal of Educational Psychology, 91, 537 548. http://dx.doi.org/10.1037/00220663.91.3.537

Rodriguez, I., Del Valle, S., De la Vega, R. (2018). Revisión nacional e internacional de las competencias profesionales de los docentes de Educación Física. Retos, 34, 383-388. https://doi.org/10.47197/ retos.v0i34.58609.

Rots, I., Kelchtermans, G. \& Aelterman, A. (2012). Learning (not) to become a teacher: A qualitative analysis of the job entrance issue. Teaching and Teacher Education. 28. 1-10. Doi: 10.1016/ j.tate. 2011.08 .008

Ryan, R.M.; Deci, E.L. (2017). Self-Determination Theory: Basic Psychological Needs in Motivation, Development, and Wellness. Guilford Press: New York, NY, USA.

Silvia, P.J. (2008) 'Interest - the curious emotion', Current Directions. Psychological Science 17, 5760.

Solbazcher, C. (2006). Improving learning competence in schools: what relevance does empirical research in this area have for teacher training? European Journal of Teaching Education, 29(4), 533-544

Solomon, D., Battistich, V., Watson, M., Schaps, E., \& Lewis, C. (2000). A six-district study of educational change: Direct and mediated effects of the child development project. Social Psychology of Education, 4, 3-51.

Standage, M., Duda, J. L., \& Ntoumanis, N. (2005). A 
test of self-determination theory in school physical education. The British Journal of Educational Psychology, 75, 411-433. DOI:10.1348/ 000709904X22359

Stein, M. K., \& Wang, M. C. (1988). Teacher development and school improvement: The process of teacher change. Teaching and Teacher Education, 4, 171-187.

Stratton, G., Fairclough, S. J. \& Ridgers, N. D. (2008). Physical activity levels during the school day. In, A. L. Smith, y S. J. H. Biddle (eds), Youth Physical Activity and Sedentary Behavior. Challenges and Solutions (pp. 321-350). Champaign, IL: Human Kinetics.

Struyven, K. \& Meyst, M. (2010). Competence-based teacher education: Illusion or reality? An assessment of the implementation status in Flanders from teachers' and students' points of view. Teaching and Teacher Education 26. 1495-1510. Doi: 10.1016/ j.tate.2010.05.006.

Tang, S.Y. F., Wong, A. K.Y., \& Cheng, M. M. H. (2016). Configuring the three-way relationship among student teachers' competence to work in schools, professional learning, and teaching motivation in initial teacher education. Teaching and Teacher Education, 60, 344-354.http:/ /dx.doi.org/10.1016/ j.tate.2016.09.001 0742-051X/

Taylor, I. M., Ntoumanis, N., \& Standage, M. (2008). A self-determination theory approach to understanding the antecedents of teachers' motivational strategies in physical education. Journal of Sport and Exercise Psychology, 30, 75-94. DOI: 10.1123/jsep.30.1.75 - Source: PubMed

Tsai,Y., Kunter, M., Lüdtke, O., Trautwein, U. \& Ryan, R. M. (2008). What makes lessons interesting? The role of situational and individual factors in three school subjects. Journal of Educational Psychology 100: 460-72.

Tschannen-Moran, M., Woolfolk Hoy, A., \& Hoy, W. K. (1998). Teacher efficacy: Its meaning and measure. Review of Educational Research, 68, 202-248.

UNESCO (2020). Covid-19 Impact on Education Data. COVID-19 Education Disruption and Response. The United Nations Educational, Scientific and Cultural Organization. UNESCO. Paris, France.

Van Dinther, M., Dochy, F., Seger, M. \& Braeken, J. (2013). The construct validity and predictive validity of a self-efficacy measure for student teachers in competence-based education. Studies in Educational Evaluation. 39. 169-179.doi: 10.1016/ j.stueduc.2013.05.001.

Vansteenkiste, M.; Ryan, R.M. (2013). On psychological growth and vulnerability: Basic psychological need satisfaction and need frustration as a unifying principle. J. Psychother. Integr., 23, 263-280. DOI: 10.1037/a0032359

Villardón-Gallego, L., Yániz, C., Achurra, C., Iraurgi, I., Aguilar, M. C. (2013). Learning Competence in University: Development and Structural Validation of a Scale to Measure. Revista de Psicodidáctica, vol. 18, núm. 2, 357-374.

Villaverde-Caramés, E., Fernández-Villarino, M.A., Toja-Reboredo, B, González-Valeiro, M.A. (2021). Revisión de la literatura sobre las características que definen a un buen docente de Educación Física: consideraciones desde la formación del profesorado. Retos, 41, 471-479. https://doi.org/10.47197/ retos.v0i41.84421.

Viner, R.M., Russell, S. J., Croker, H., Packer, J., Ward, J., Stansfield, C., Mytton, O., Bonell, C. \& Booy, R. (2020). School closure and management practices during coronavirus outbreaks including COVID-19: a rapid systematic review. The Lancet Child \& Adolescent Health (4) 5, 397-404. https: / / doi.org/ 10.1016/S2352-4642(20)30095-X

Waddell, M. (2018). On Adolescence: Inside Stories. London \& New York: Routledge.

Woolfolk, A. E., Rosoff, B., \& Hoy, W. K. (1990). Teachers' sense of efficacy and their beliefs about managing students. Teaching and Teacher Education, 6, 137-148.

World Health Organization (2020). Mental Health and Psychosocial Considerations during the COVID-19 Outbreak-18 March 2020. Geneva: Switzerland.

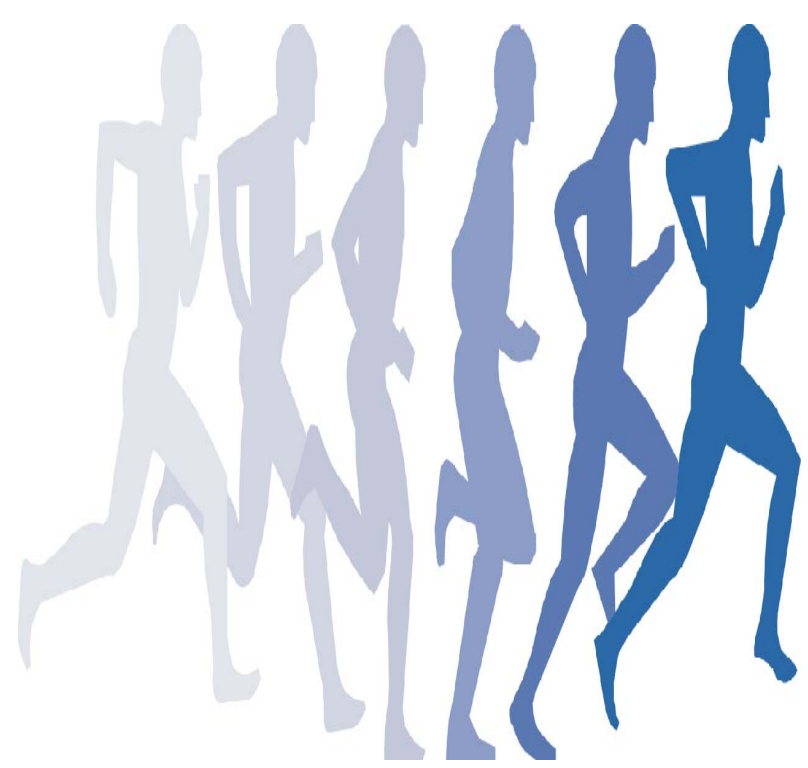

